\title{
HYDRODYNAMIC INVESTIGATION AND NUMERICAL SIMULATION OF INTERMITTENT AND EPHEMERAL FLOWS IN SEMI-ARID REGIONS: WADI MEKERRA, ALGERIA
}

\author{
KHALED KORICHI ${ }^{1,2)}$, ABDELKRIM HAZZAB ${ }^{1)}$ \\ ${ }^{1)}$ Laboratory of Modeling and Computational Methods, University of Saida, BP 138 Ennasr Saïda 20002, Algeria; \\ Mailto:kh.korichi@gmail.com \\ ${ }^{2)}$ Faculty of Engineering, Department of Civil Engineering, University of Djillali Liabes, Sidi Bel Abbes, BP 89, Sidi Bel Abbes \\ 22000, Algeria.
}

Semi-arid regions are characterized by important infrequent rainfall. They often occur in early autumn and give rise to devastating floods. Flooding problems at Wadi Mekerra, located in the Sidi Bel Abbes town (Northwest Algeria), was traditionally the main concern of researchers and government officials. In this work, the magnitude of raging flood wave in the studied catchment and the principal causes are discussed. After this, we present the main hydromorphometric features and the results of numerical simulations of flood wave. This simulation is done by using finite volume shock capturing schemes. It concerns applying the first order Godunov scheme and the second order Monotonic Central scheme. The Manning roughness coefficient was used as a calibration parameter. The comparison of numerical results with observed data confirms more stability and accuracy of applied numerical schemes in rising limb phase than in the falling limb phase. These results provide information on flood forecasting and monitoring of changes in the magnitude of the flow in Wadi Mekerra.

KEY WORDS: Semi-arid, Temporary Flows, Wadi Mekerra, Flood Wave, Saint-Venant Equations, Finite Volume, Shock Capturing.

Khaled Korichi, Abdelkrim Hazzab: HYDRODYNAMICKÝ VÝSKUM A NUMERICKÁ SIMULÁCIA OBČASNÝCH A KRÁTKODOBÝCH PRIETOKOV V SEMIARIDNÝCH OBLASTIACH: WADI MEKERRA, ALŽÍR. J. Hydrol. Hydromech., 60, 2012, 2; 114 lit., 13 obr., 7 tab.

Semiaridné oblasti sú charakterizované významnými občasnými dažd’ami. Vyskytujú sa spravidla v jeseni a spôsobujú devastačné povodne. Povodne vo Wadi Mekerra v meste Sidi Bel Abbes (severozápadné Alžírsko) sú často problémom pre výskumníkov a vládnych úradníkov. Práca analyzuje devastačné povodne v tomto povodí. Okrem toho sa uvádzajú najdôležitejšie hydromorfomertrické charakteristiky a výsledky simulácií povodňovej vlny. Simulácia je aplikáciou Godunovovej schémy prvého rádu a Monotonickej centrálnej schémy druhého rádu. Ako kalibračný parameter bol použitý Manningov súčinitel' drsnosti. Porovnanie simulovaných a pozorovaných údajov potvrdzuje väčšiu stabilitu a presnost' počas rastúcej vetvy prietokovej vlny, ako je tomu v klesajúcej fáze. Tieto výsledky sú informáciou o možnostiach predpovede a monitoringu povodní vo Wadi Mekerra.

KLÚČOVÉ SLOVÁ: semi-aridný, občasné povodne, Wadi Mekerra, povodňová vlna, rovnice SaintVenanta, konečný objem, pohltenie nárazu.

\section{Introduction}

Almost all natural phenomena can produce disasters; however flooding is the most important in terms of lost materials and human lives (Mudd, 2006; Huang et al., 2010). Prediction and control of damage caused by these disasters require special identification of vulnerable areas and determination of factors amplifying the magnitude of generated damage (Hansson et al., 2008 ; Jonkman et al., 2008).

The inundations risk is considered as the product of the occurrence probability of floods and consequences associated with these events (Raaijmakers et al., 2008). By possessing a diagram of the situation, it would be possible not only to manage risk, take the most appropriate steps to eliminate loss in life and minimize property loss, but also have di- 
verse opportunities to provide the appropriate dimensioning of hydraulic structures (Breton and Marche, 2001).

The estimated impact of floods and the risk assessment that follows are issues for which the literature provides different analysis approaches (Gregory et al., 1993; Haase et al., 2003 ; Olfert et Schanze, 2008). The used tools for the floods treatment are flow modelling, analysis of flood frequency and evaluation of potential annual cost of damage (Boyle et al., 1998).

Semi-arid regions are characterized by infrequent rainfall but sometimes very important (Colombani et al., 1984 ; Pedro et al., 2006). These cloudbursts often give rise to flooding whose consequences are sometimes unforeseen (Hansson et al., 2008). However, streams in semi arid areas are characterized by irregular flow and a strong hydrologic fluctuation (Arab et al., 2004). During the year, intermittent flows dominate in most Wadis (Argyroudi et al., 2009). A mismatch between lotic and lentic conditions, is thus noticed (Morais et al., 2004).

It should be noted that this type of region where most rivers are ephemeral, do not have, to date a global treatment approach. This is justified by many reasons. (a) The lack of data that represents a handicap to study of changes in hydrological balance (Sivapalan et al., 2003). (b) The occasional change of climate and anthropic conditions, which leads to an imbalance in the hydrologic fluxes and physical characteristics of the basin (Puigdefabregas and Mendizabal, 1998; Xoplaki et al., 2004; López-Moreno et al., 2007). (c) The high variability of ephemeral events and the hydrology of dryland zones. This implies a strong nonlinearity of explored models (Nouh, 2006; Hreiche et al., 2007; Kingumbi et al., 2007; Lajili-Ghezal, 2007; McIntyre et al., 2007; Nasri, 2007). (d) Spatial heterogeneity generates a gradual change in the hydraulic capacity. So flood risks are confirmed (Lebdi et al., 2006).

Historical hydrology (Barriendos and Rodrigo, 2006; Brázdil and Kundzewicz, 2006) represents the best tool that can respond to treatment of these issues. The effort is focused on the methodology. Thus, robust methods are designed to ensure a compromise between the applicability and accuracy, especially in rainfall-runoff modelling field, which represents a major preoccupation in arid and semi-arid catchments (Camarasa and Tilford, 2002; Benkaci and Dechemi, 2004; Nasri et al., 2004; Cudennec et al., 2005; Hreiche et al., 2007; Moussa et al., 2007; McIntyre et al., 2007; Ouachani et al.,
2007; Chaponnière et al., 2007; (Pilgrim et al., 1988; Hughes, 1995; Sharma and Murthy, 1998; Wheater et al., 2006). Other approaches propose the coupling of hydrological, hydraulic models and statistical analysis. This is especially the combination of surface and groundwater hydrology (Rozos et al., 2004; Bouri et al., 2007; Kingumbi et al., 2007), or between the stochastic and dynamic approaches (Hreiche et al., 2007; Lajili-Ghezal, 2007).

Recent works have been performed to calibrate and validate various models for Wadis whose flow regime is intermittent or even ephemeral (cf. Tab. 1). One cites innovative studies distributed in such semi-arid zones. It is about of hydrological model developed for Australian drylands (Costelloe et al., 2005), or hydro-biological model for the same type of zone in Brazil (Pedro et al., (2006). in the Middle East, Alexandrov et al., (2007) quantify the sediment transport in the Negev watershed. Modern techniques involve the use of Digital Elevation Models (DEM) for flood forecasting by parameterizing algorithms for two-dimensional hydrodynamic flood simulation (Sanders, 2007).

In Algeria, we can refer to the studies of Dechemi et al., (1994) in the Tafna watershed and the works of Achit and Ouillon (2007) for the Wadi Abd.

By tracking all these methods, numerical modelling of transient and complexes free surface flows can be explored as an interesting approach. Horritt and Bates (2002) present an example of a twodimensional numerical model of flood wave propagation. Mathematically, floods waves can be governed by the Saint-Venant model which is a nonlinear hyperbolic system of partial differential equations. Nonlinear problems represent shock and rarefaction waves. To overcome the handicap in the treatment of non-linearity, several solving strategies have been developed (Liggett and Cunge, 1975; Cunge et al., 1980; Guinot, 2010).

Among all numerical approaches, the shock capturing finite volume methods have several advantages, since they combine between the simplicity of the finite difference method and the flexibility of the finite element method (Godunov, 1959; Lax and Wenderoff, 1960; Van Leer, 1977; Leveque, 2004 and Toro, 2006).

However, in the treatment of real problems (eg: channel with complex geometry), some schemes still need to overcome numerous difficulties (Wang et al., 2000). For instance, the treatment of the 
$\mathrm{T}$ a $\mathrm{b} 1 \mathrm{e}$ 1. Targeted papers relevant to flood wave in Wadis and rivers.

\begin{tabular}{llll}
\hline Reference & River basin or region & Type & Main contribution \\
\hline $\begin{array}{l}\text { Cherif } \text { et al. (2009) } \\
\text { Dechemi } \text { et al. (1994) }\end{array}$ & Wadi Mekerra, Algeria & Ephemeral & Statistical Study \\
$\begin{array}{l}\text { Horritt } \text { and Bates } \\
\text { (2002) }\end{array}$ & Severn river, UK & Intermittent & Statistical study \\
Nasri et al. (2004) & $\begin{array}{l}\text { El Gouazine and Dekekira, Tuni- } \\
\text { sia }\end{array}$ & Intermittent & Flood impact \\
Costelloe et al. (2005) & Lake Eyre, Australia & Both & Hydrological models \\
$\begin{array}{l}\text { Pedro } \text { et al. (2006) } \\
\text { Alexandrov } \text { et al. (2007) }\end{array}$ & Taperoá, Brasil & Eshtemoa, Negev & Intermittent \\
$\begin{array}{l}\text { Achit } \text { and } \text { Ouillon } \\
\text { (2007) }\end{array}$ & Wadi Adb, Algeria & Ephemeral & Hydro-biological model \\
Bracken et al. (2008) & Nogalte and, Torrealvilla, Spain & Both & Sediment tranport \\
Sanders (2007) & Santa Clara River & - & Rainfall and flood \\
\hline
\end{tabular}

source term is one of the difficulties that may result in significant numerical error in such cases. This has been a problem that many researchers are seeking to solve (Leveque, 1998; Garcia-Navarro and Vasquez-Cendon 2000; Zhou et al., 2001) and more recently (Roger et al., 2003; Audusse et al. 2004; Benkhaldoun et al. 2007; Kesserwani and Liang 2010; Liang and Wang 2010; Lee and Wright 2010).

Sidi Bel Abbes town makes part of semi-arid regions. It is faced to floods phenomena and inundations that occur in a catastrophic manner (Stucky, 2005). These floods are frequent, recurrent and present a major constraint on economic and social development $(D G P C, 2008)$. The management of this phenomenon presents a particular concern for public authorities. The objective is to conceive a hydraulic management project that responds to the city protection requirements against floods while preserving the benefits arising from the plain's immersion through an important contribution of natural fertilizers elements and the aquifers filling.

Having regard to the importance of these accentuated flooding, several preventive works have been proposed. Certain concern the study of the flooding phenomenon in Mekerra catchment (Borsali et al., 2005). Currently, the works of SAFEGE group constitute a promising start in the implementation of an alert system which provides flood and also for the delimitation of risk zones.

In this paper, we present numerical simulation of a flood wave in October 1995, at Wadi Mekerra. This contribution aims to identify potential risk areas, the wave magnitude and the time required to alert threatened agglomerations. The numerical simulation is achieved by applying finite volume methods. It is about of shock capturing first-order Godunov scheme and Monotonic Central second order scheme. These schemes have proved their ability to obtain robust, stable and monotone solutions (Ying et al., 2004; George, 2006; Begnudelli, 2007). Such approach is based on solving the SaintVenant equations by numerical treatment of Riemann problem. The simulation results are promising and confirm the stability and accuracy of these numerical schemes.

The remainder of the paper is organized as follows. "Study area" presents a global description and General information about the study site, flow regime and the chronology of floods generated at Wadi Mekerra. "Mathematical model and methods" presents governing equations of Saint-Venant model including numerical methods in which Godunov scheme and Monotonic Central scheme are briefly presented. "Numerical tests" presents a series of Dam failure and flood wave tests in order to verify and validate the model. We end by a Summary and Conclusion.

\section{Study area: Wadi Mekerra}

\section{General information}

The Wadi Mekerra is the main stream in the watershed which bears the same name. This latter is part of the great Macta basin. It occupies a great part of Sidi Bel Abbes town (Northwest of Algeria). It is located between the latitudes $34^{\circ} 31^{\prime} \mathrm{N}$ and $35^{\circ} 21^{\prime} \mathrm{N}$ and longitudes $1^{\circ} 16^{\prime} \mathrm{O}$ and $0^{\circ} 58^{\prime} \mathrm{O}$ (cf. Fig. 1). The Wadi has its source in the high valleys of the steppe at an altitude of around $1250 \mathrm{~m}$. To the right of Sidi Bel Abbes city, the Wadi drains an area of $3000 \mathrm{~km}^{2}$ and develops a talweg of $115 \mathrm{~km}$ in length. The catchment is elongated and northsouth oriented. Its relief is mountainous in the hills. The absolute heights of the watershed crest are 
1000 to $1100 \mathrm{~m}$ in the north, $1200 \mathrm{~m}$ in the oust, 1200 to $1260 \mathrm{~m}$ in the south and 870 to $1460 \mathrm{~m}$ at the east of Mekerra basin. $48 \%$ of the catchment area has an elevation above $1000 \mathrm{~m}$, wich explains the torrential streams character. The average slope of Wadi is $5.5 \%$. The Mekerra watershed is divided into three sub-basins (Hacaiba, Sidi Ali Benyoub and Sidi Bel Abbes city). Each one has a gauging station. Tab. 2 summarizes the main hydromorphometric characteristics of each sub-basin.

The Mekerra catchment is divided into three hydrological areas that manage the hydrological response of the Wadi. It is about of the floods production zone at the upstream, discharges transfer zone in middle and expansion zone in downstream.

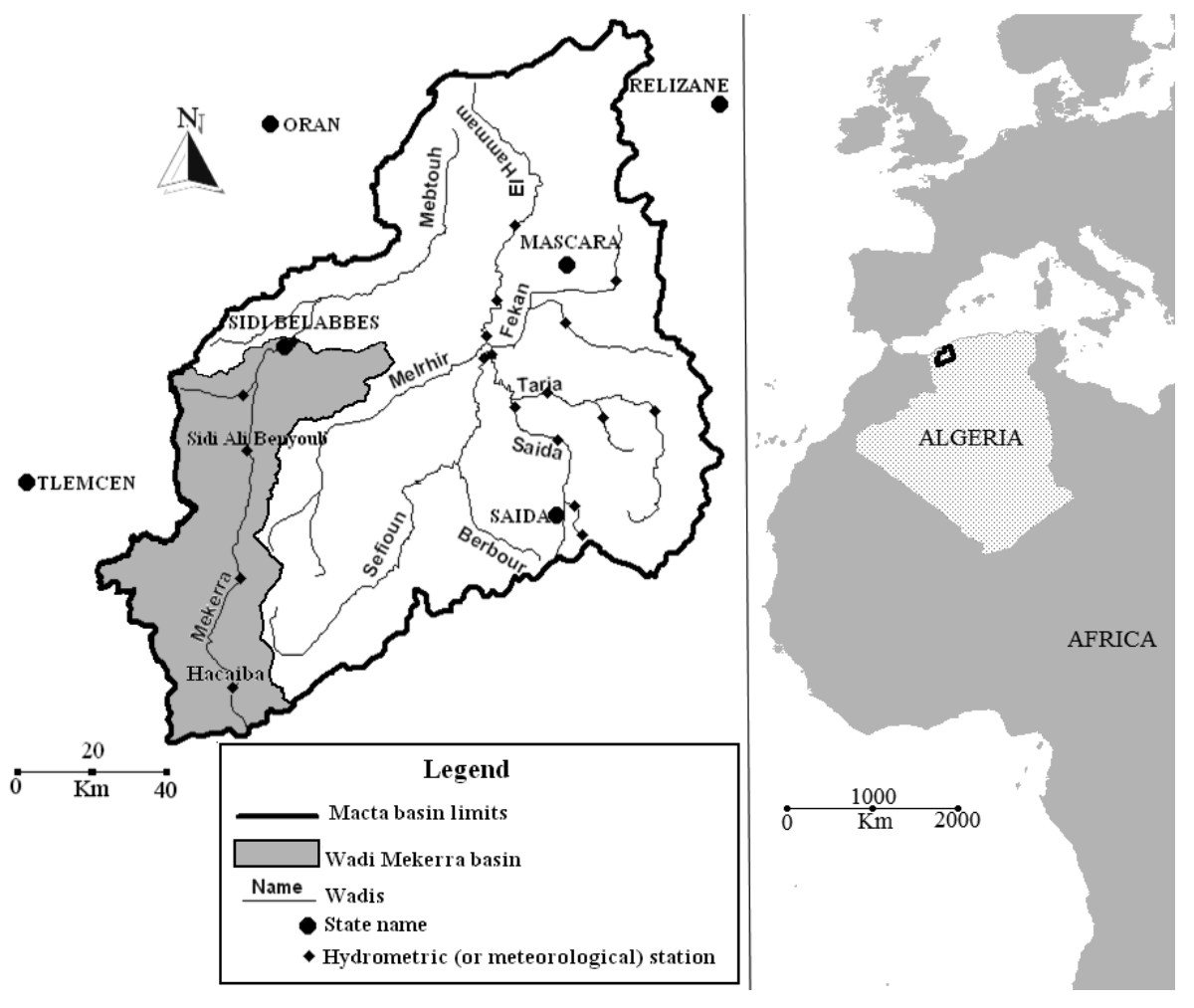

Fig. 1. Location of the Mekerra watershed and its major hydrometric stations.

$\mathrm{T} \mathrm{a} \mathrm{b} 1$ e 2. Main hydromorphometric features of the Mekerra sub-basins.

\begin{tabular}{lccccc}
\hline Features & Symbol & Unit & $\begin{array}{c}\text { Haçaiba } \\
\text { Station } \\
(1946)\end{array}$ & $\begin{array}{c}\text { Sidi Ali Benyoub } \\
\text { Station } \\
(1949)\end{array}$ & $\begin{array}{c}\text { Sidi Bel Abbes } \\
\text { Station } \\
(1918)\end{array}$ \\
\hline Surface & $\mathrm{S}$ & {$\left[\mathrm{km}^{2}\right]$} & 957 & 1890 & 3000 \\
Compactness index & $\mathrm{K}_{\mathrm{C}}$ & {$[\mathrm{km}]$} & 1.15 & 1.29 & 1.43 \\
Characteristic height & $\mathrm{H}_{\max }$ & {$[\mathrm{m}]$} & 1440 & 1715 & 1714 \\
Roche Slope index & $\mathrm{H}_{\min }$ & {$[\mathrm{m}]$} & 925 & 635 & 437 \\
Wadi's length & $\mathrm{I}_{\mathrm{p}}$ & {$[\%]$} & 0.099 & 0.0936 & 0.0913 \\
Drainage density & $\mathrm{L}$ & {$[\mathrm{km}]$} & 54.00 & 92.00 & 115.00 \\
Torentiallity & $\mathrm{D}_{\mathrm{d}}$ & {$[-]$} & 0.06 & 0.050 & 0.02 \\
Time of concentration & $\mathrm{C}_{\mathrm{T}}$ & {$[-]$} & 0.20 & 31.25 & 6.86 \\
\hline
\end{tabular}

Vegetation and geology

Across the Mekerra watershed, only $25 \%$ of subsoil is impermeable. The northern part is much more permeable than the southern part. Tab. 3 resumes the land cover in the Mekerra watershed
(ANAT, 2000). It is thus noted that the vegetation cover in the basin is developed in an irregular manner. At the downstream of Ras El Ma city appear lands covered with Alfa, which towards the north give way to brushland. At the upstream, there are cereals, vines and citrus occupying Sidi Ali 
Benyoub zone. Forests cover over $20 \%$ of the basin area $(D G P C, 2000)$.

The influence study of the vegetation on the layout and the stream aspect has been described by Filliol (Filliol, 1954). Depending to rates of banks integral fixation or bed partial fixation by vegetation, it results in lateral erosion processes or depth erosion. There's also the factor of flow velocity influence. According Martinez-Mena et al., (1999) and Rachman et al., (2003), vegetation cover can reduce the rainfall kinetic energy at $50 \%$ and the runoff power to $75 \%$.

T a b le 3. Mekerra basin landcover.

\begin{tabular}{lll}
\hline Landcover & $\begin{array}{l}\text { Surfaces } \\
{\left[\mathrm{km}^{2}\right]}\end{array}$ & \% surfaces \\
\hline Forest and maquis & 500.3 & 27.61 \\
Annual cultures & 649.1 & 35.82 \\
Alfa & 194.1 & 10.71 \\
Agglomerations & 21.16 & 1.17 \\
Soil conservation works & 7.56 & 0.42 \\
Unproductive land & 50.80 & 2.8 \\
Route & 103.9 & 5.73 \\
\hline
\end{tabular}

Three main sets of soil dominate the Mekerra catchment. It is about of calcic brown soil, calcareous soil and alluvial soil. The first two types belong to the magnesium-calcic soil class. These soils are deeper, having a structure generally well developed granular or lumpy type in the surface horizon and polyhedral in the depth (Bouasria et al., 2010). On the agricultural front, their complex adsorbent is saturated with calcium and magnesium, the $\mathrm{pH}$ is above 6.8 . The alluvial soils belong to the poorly evolved class. These soils are encountered on the Wadi terraces and characterized by a poorly differentiated and low-structured profile. This explains that these soils are good for agriculture (Askri et al., 1993).

\section{Climate, rainfall and runoff}

Situated in the semi-arid climatic region, the Mekerra catchment is characterized by hot dry summers spanning from April to August and a relatively mild winter and wet from October to March. The average annual temperature is around $15^{\circ} \mathrm{C}$ and average interannual day of frost is about 35 days. Prevailing winds are from northwest and west. The interannual average speed is about $20 \mathrm{~m} \mathrm{~s}^{-1}$. Rainfall is irregular, characterized by intense autumnal rains causing major floods (cf. Fig. 2) whose effects are felt between Boukhanifis and Sidi Bel Abbes agglomeration. During wet years the amount of rainfall may exceed $800 \mathrm{~mm}$ (cf. Fig. 3). In dry years, it decreases to $110 \mathrm{~mm}$. The average interannual rainfall is around $400 \mathrm{~mm}$.

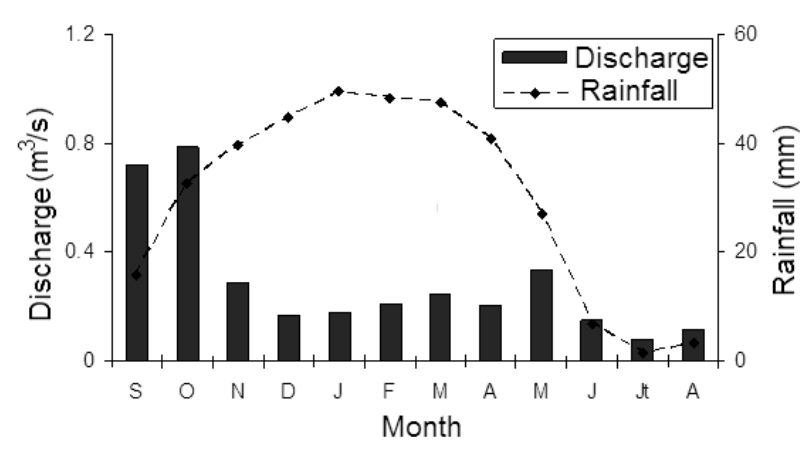

Fig. 2. Variability of mean monthly precipitation and water discharge in Wadi Mekerra (Sidi Bel Abbes gauge Station, 1942-2001).
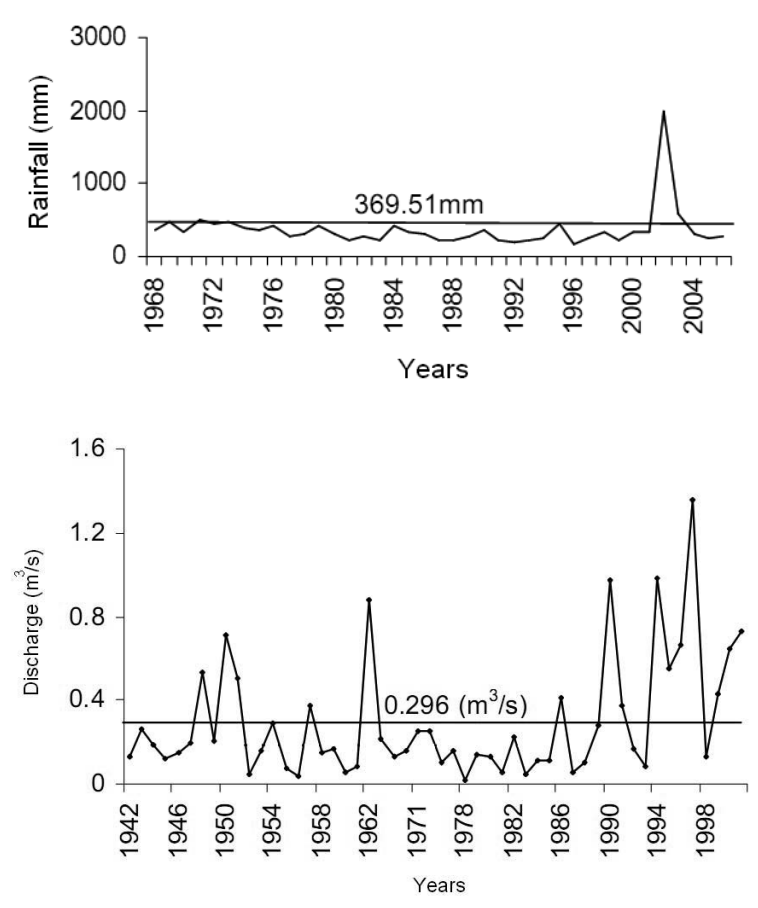

Fig. 3. Variability of annual precipitation (top) and mean annual water discharge (down) in Wadi Mekerra (Sidi Bel Abbes gauge Station, 1942-2001).

Fig. 3 shows in particular a strong flow fluctuations during the period (1942 to 2001) in which the Wadi Mekerra has passed through two long dry periods. The first lasts for nine (9) years (1952 to 1962) where the mean annual discharge was 0.221 $\mathrm{m}^{3} \mathrm{~s}^{-1}$. The second period has lasted seventeen (17) years from 1968 to 1985 with an average discharge 
of about $0.141 \mathrm{~m}^{3} \mathrm{~s}^{-1}$. It is interesting to note that the lack of pluviometric inflows observed from the mid-seventies, confirms the drought in North Africa over the past four decades (Tardy and Probst, 1992). This lack is manifested in a dramatic decrease in water supplies drained by Maghrebi Wadis. Compared with normal flows, a decrease of $67 \%$ is observed in the North-West of Algeria (Meddi et al., 1998).

\section{Floods of Wadi Mekerra}

\section{Overview}

Inudation's problem generated by cyclical floods of Wadi Mekerra has always constituted one of the main concerns of the managers of Sidi Bel Abbes city. Further to observations made during the various floods recorded, we can relate it to several causes, namely: (1) Intense and irregular cloudburst at high Mekerra can reach $200 \mathrm{~mm} \mathrm{~h}^{-1}$. (2) Morphology of Mekerra watershed, particularly elongate, where time of concentration is very low $(T c=$ $=9$ hour). (3) Narrowing of the Wadi section at some stretches and hydraulic structures. (4) Almost-total obstruction of the Wadi's sections by sediments carried and deposited by anterior floods. (5) The downstream affluents have very low slopes if not negative. (6) Unplanned urbanization in the banks of the Wadi (DGPC, 2000). This factor affects seriously the magnitude of floods. Indeed, for the semi-arid basin (Wadi Medjerda in Tunisia) Lebdi et al., (2006); Zahar and Albergel (2006) have shown that people's sensitization affects the vulnerability of flood risks.
Tab. 4 sums up the main damage, victims, injured and homeless, caused by the floods in Wadi Mekerra due by thunderstorms and heavy rains during twenty five years (1978-2000). One can add, agricultural land inundation, undermining of the Wadi banks and vegetation degradation.

Fig. 4 shows the major floods in Wadi Mekerra presented by peak discharges between (19422001). We observe in particular that the magnitude of floods has increased remarkably during the decade (1990-2001). Taking into account observations of 34577 instantaneous discharges for the period (1942-2001), spread over the three gauging stations (Hacaiba, Sidi Ali Benyoub and Sidi Bel Abbes) a statistical study showed that the class of dominants discharges is that less than $10 \mathrm{~m}^{3} \mathrm{~s}^{-1}$. While the high discharges (more than $200 \mathrm{~m}^{3} \mathrm{~s}^{-1}$ ) represents only $0.01 \%$ (Stucky, 2005) (cf. Tab. 5).

The daily flow duration curve (cf. Fig. 5), shows a very pronounced concavity reflecting the irregularity of the flow regime. A special flow discharges are shown in Tab. 6.

\section{Flow regime}

The flow regime of the Wadi Mekerra was investigated based on mean daily discharges recorded at the station of Sidi Bel Abbes for 59 years (1942$-2001)$. The average number of days without flow reaches 328 days per year ( $90 \%$ of the year). This indicates the intermittent nature of the Wadi. In referring to the literature for the flow regimes characterization of Wadis in this type of region, we note the existence of several classifications. Some of them cover the world, others are continental

T a b l e 4. Flood statistics in Sidi Bel Abbes City (1978-2000).

\begin{tabular}{|c|c|c|c|c|c|}
\hline \multirow{2}{*}{$\begin{array}{l}\text { Inundated area } \\
\text { [ha] }\end{array}$} & \multirow{2}{*}{ Location } & \multirow{2}{*}{ Date } & \multirow{2}{*}{ Cause } & \multicolumn{2}{|c|}{ Number of sinister } \\
\hline & & & & Dead & Homeless families \\
\hline 160 & Ain El Berd & $02 / 10 / 78$ & Thunderstorm & - & 08 \\
\hline 24 & Ben Badis & $06 / 03 / 80$ & Heavy precipitation & - & 08 \\
\hline 10 & Boukhanifis & $06 / 03 / 80$ & Heavy precipitation & - & 04 \\
\hline Not estimated & Sidi Bel Abbes & $04 / 10 / 86$ & Thunderstorm & 01 & 200 \\
\hline Not estimated & Sidi Bel Abbes, Telagh & $30 / 04 / 90$ & Thunderstorm & 02 & 130 \\
\hline Not estimated & $\begin{array}{l}\text { Sidi Bel Abbes, Boukhanifis, Sidi } \\
\text { Lahcen, Hassi Zahana, Hassi Dahou, } \\
\text { Oued Sefioun }\end{array}$ & $29 / 09 / 94$ & Thunderstorm & 01 & 22 \\
\hline Not estimated & Sidi Hamadouche, Ain El Berd & $16 / 10 / 94$ & Thunderstorm & - & 70 \\
\hline Not estimated & Sidi Bel Abbes, Sfisef, Ain El Berd & $05 / 12 / 95$ & Thunderstorm & - & 03 \\
\hline Not estimated & Hassi Zahan & $13 / 06 / 96$ & Thunderstorm & - & 02 \\
\hline Not estimated & Moulay Slissen & $17 / 08 / 97$ & Thunderstorm & 01 & 34 \\
\hline Not estimated & Sidi Bel Abbes & $27 / 09 / 97$ & Thunderstorm & 01 & - \\
\hline Not estimated & Sidi Bel Abbes & $13 / 12 / 97$ & Thunderstorm & 01 & 05 \\
\hline Not estimated & Ras El Ma & $27 / 07 / 00$ & Thunderstorm & - & 100 \\
\hline
\end{tabular}




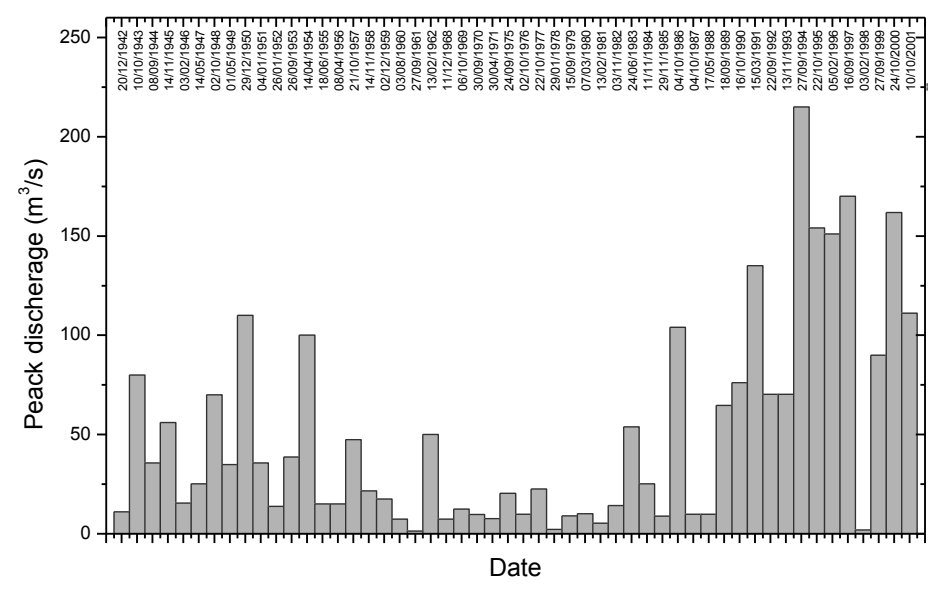

Fig. 4. Peak annual discharges recorded at Wadi Mekerra (1942-2001).

T a b l e 5. Distribution in [\%] of floods in Wadi Mekerra (1942-2001).

\begin{tabular}{llllll}
\hline Classes of discharges $\left[\mathrm{m}^{3} \mathrm{~s}^{1}\right]$ & $>200$ & $200-100$ & $100-50$ & $50-10$ & $<10$ \\
$\begin{array}{l}\text { Frequency } \\
{[\%]}\end{array}$ & 0.01 & 0.5 & 1.44 & 5.29 & 92.77 \\
\hline
\end{tabular}

T a b 1 e 6. Special discharge recorded at Wadi Mekerra (1942-2001).

\begin{tabular}{lllllllll}
\hline $\begin{array}{l}\text { Duration } \\
\text { [days/year] }\end{array}$ & $\begin{array}{l}\text { Max } \\
\text { flow }\end{array}$ & $>10$ & $>30$ & $>90$ & $>180$ & $>270$ & $>355$ & $\begin{array}{l}\text { Low } \\
\text { flow }\end{array}$ \\
$\begin{array}{l}\text { Discharge } \\
{\left[\mathrm{m}^{3} \mathrm{~s}^{-1}\right]}\end{array}$ & 1.473 & 1.357 & 0.869 & 0.318 & 0.142 & 0.065 & 0.003 & 0.022 \\
\hline
\end{tabular}

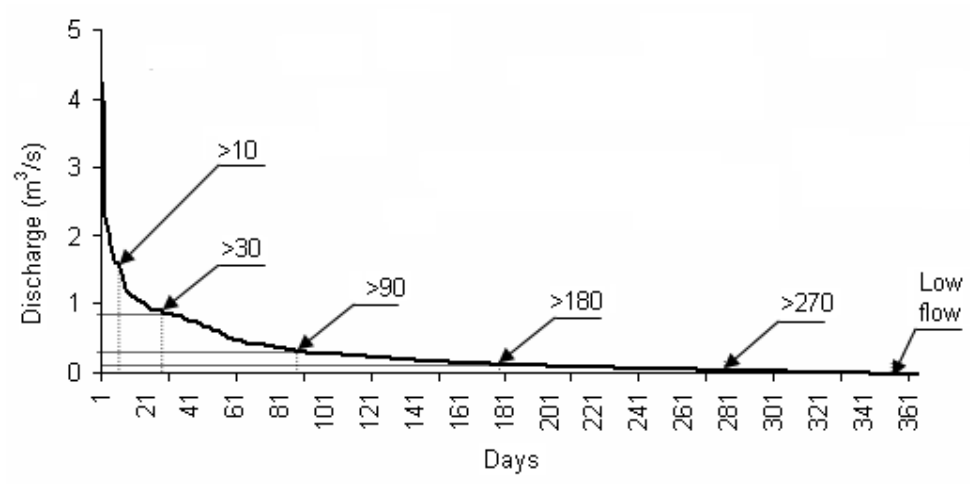

Fig. 5. Daily flow duration curve for Wadi Mekerra (1942-2001).

(Smakhtin, 2001). These classifications are based on several hydrological parameters. Poff and Ward (1989) have developed a conceptual model based on a hierarchical classification of the main components of the flow regime, namely (intermittency and flooding frequency). In tropical regions of Australia, Molière et al., (2009) has developed a classification analysis based on discharge variability, the flood regime model and the intermittency indexes. This analysis indicates that rivers could be classified as permanent, seasonal dry-seasonal and sea- sonal-intermittent. Oueslati et al. (2010) note that the stations in eastern and southern parts of the Mediterranean basin are more intermittent and predictable in compared to those located in west and north. In fact, identified works for the case of Algeria's catchments, confirm this finding. As such, we cite the studies of Terfous et al., (2001) in Wadi Mouilah; Wadi Mina in eastern Algeria (Achite and Meddi, 2005); Wadi Abd (Achite and Ouillon, 2007) in western Algeria and Wadi Haddad in central Algeria (Touaïbia et al., 2001). 
In our case, the data exploration confirms the ephemeral character of Wadi Mekerra throughout the studied period except between 1997 to 1999 where he was intermittent. Further, we find that the flow regime of Wadi Mekerra hardly reflects the intensity of the heavy rains. Because, a high daily discharge does not necessarily result in a high mean annual discharge. This was well observed in 1997 (cf. Tab. 7) where the total volume flowed during the flood was $2,64.10^{6} \mathrm{~m}^{3}$ corresponding to a maximum instantaneous discharge reaching $170 \mathrm{~m}^{3} \mathrm{~s}^{-1}$. While in 1999 the total volume flowed during the flood was $2,63.10^{6} \mathrm{~m}^{3}$ corresponding to a maximum instantaneous discharge which was about $90 \mathrm{~m}^{3} \mathrm{~s}^{-1}$.

Floods are more frequent and severe in autumn than in spring. They are characterized by a rapid rising in flood phase and a slower and regularized descent during the recession. This regularization is justified by the spreading fields in the downstream. In the recession phase, the water in spreading extents and the water stored in the alluvium (banks and bed) return by overflow into the streams. On the contrary, water stored in the alluvial part of the Wadi basin assists to the prolongation of the flood recession and contributes toward the extension of low flow during the initial phase of the dry period. The recharge is relatively slow, which favors the filling of the groundwater table and the settling of natural fertilizers elements. Peak discharges are larger in high Mekerra (Sidi Ali Benyoub) that in its lower part (Sidi Bel Abbes City), where there has been a flat spotting (lamination or natural regulation) of the flood wave (Sadeg, 2003).

T a b l e 7. Main total volumes flowed at Wadi Mekerra.

\begin{tabular}{|c|c|c|c|c|c|}
\hline \multirow{2}{*}{ Flood date } & \multicolumn{2}{|c|}{$\begin{array}{l}\text { Maximum instantaneous } \\
\text { discharge }\end{array}$} & \multirow{2}{*}{$\begin{array}{l}\text { Total volume flowed } \\
\text { during the flood } \\
{\left[10^{6} \mathrm{~m}^{3}\right]}\end{array}$} & \multirow{2}{*}{$\begin{array}{l}\text { Mean total volume } \\
\text { flowed in year } \\
{\left[10^{6} \mathrm{~m}^{3}\right]}\end{array}$} & \multirow{2}{*}{$\begin{array}{l}\text { [\%] flood volume } \\
\text { relative to mean } \\
\text { annual volume }\end{array}$} \\
\hline & $\begin{array}{l}\text { Gross } \\
{\left[\mathrm{m}^{3} \mathrm{~s}^{-1}\right]}\end{array}$ & $\begin{array}{l}\text { Specific } \\
{\left[1 / \mathrm{s} / \mathrm{km}^{2}\right]}\end{array}$ & & & \\
\hline $29 / 12 / 1950$ & 110 & 60.71 & 6.52 & 22.30 & 29.24 \\
\hline $14 / 04 / 1954$ & 100 & 55.19 & 5.65 & 9.14 & 61.82 \\
\hline 04/10/1986 & 104 & 57.40 & 4.82 & 12.89 & 37.39 \\
\hline $15 / 03 / 1991$ & 135 & 74.50 & 9.29 & 11.88 & 78.20 \\
\hline 27/09/1994 & 215 & 118.65 & 4.78 & 30.94 & 15.45 \\
\hline $22 / 10 / 1995$ & 154 & 84.99 & 7.99 & 17.41 & 45.89 \\
\hline 05/02/1996 & 151 & 83.33 & 8.64 & 20.94 & 41.26 \\
\hline $16 / 09 / 1997$ & 170 & 93.82 & 2.64 & 42.79 & 6.17 \\
\hline 27/09/1999 & 89.88 & 49.60 & 2.63 & 13.67 & 19.24 \\
\hline $24 / 10 / 2000$ & 161.8 & 89.29 & 6.85 & 20.45 & 33.50 \\
\hline $10 / 10 / 2001$ & 111.17 & 61.35 & 5.19 & 23.12 & 22.45 \\
\hline
\end{tabular}

\section{Mathematical model and methods}

\section{Governing equations}

One-dimensional unsteady flows in a natural river (Wadi) with irregular cross-section may be described by the Saint-Venant equations (SaintVenant, 1871) which is derived from the mass and momentum conservation principles based on hydrostatic pressure distribution of incompressible fluid. The conservative matrix form of these equations is written as:

$$
\frac{\partial U}{\partial t}+\frac{\partial F}{\partial x}=S(U)
$$

where $U, F(U)$ and $S(U)$ are respectively, the vectors of conserved variables, fluxes and sources term, defined ad follows:

$$
U=\left[\begin{array}{l}
A \\
Q
\end{array}\right], F(U)=\left[\begin{array}{l}
Q \\
\frac{Q^{2}}{A}
\end{array}\right] \text { and }
$$

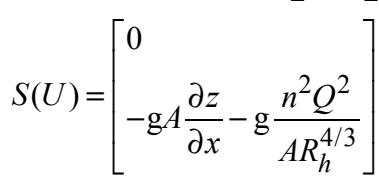

where $A$ - cross-sectional area $\left[\mathrm{m}^{2}\right], Q$ - discharge $\left[\mathrm{m}^{3} \mathrm{~s}^{-1}\right], \mathrm{g}-$ gravitational acceleration $\left[\mathrm{m} \mathrm{s}^{-2}\right] ; Z-$ water level [m] (cf. Fig. 6), $n$ - Manning coefficient $\left[\mathrm{s} \mathrm{m}^{-1 / 3}\right], R=A / P$ - hydraulic radius and $P$ - wetted perimeter of the channel $[\mathrm{m}]$. The above form of the Saint-Venant equations is commonly used in engineering practice. 


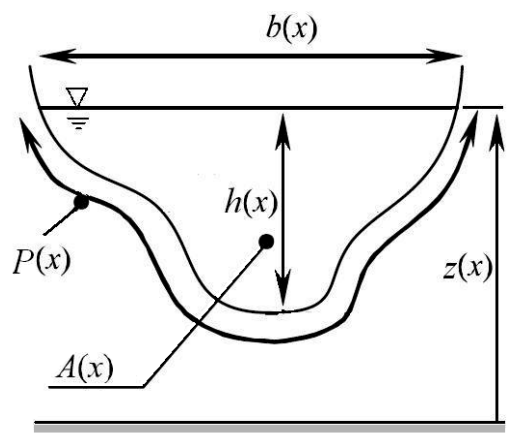

Fig. 6. Definition sketch of cross-sectional geometry.

Shallow water equations represent a nonlinear hyperbolic system of PDEs, where the Jacobian matrix

$\mathrm{J}=\frac{\partial F(U)}{\partial U}=\left(\begin{array}{cc}0 & 1 \\ -u^{2}+\mathrm{g} h & 2 u\end{array}\right)$

is diagonalisable with real and distinct eigenvalues $\lambda^{1}=u-\sqrt{g h}$ and $\lambda^{2}=u+\sqrt{g h}, u$ is the average flow velocity $\left[\mathrm{m}^{2} \mathrm{~s}^{-1}\right]$. The nonlinearity in the SaintVenant system presents shock and rarefaction waves.

\section{Numerical methods}

Among all the numerical techniques, the finite volume method is well adapted to treat conservation, hyperbolic and nonlinear problems such as Saint-Venant equations. This method is based on the discretization of the integral form, by subdividing the domain in a number of finite volumes (cells). The approximate conserved variable $U_{i}^{n}$ represents the average value over each cell. It is defined at the cell centres as

$$
U_{i}^{n} \approx \frac{1}{\Delta x} \int_{C_{i}} U\left(x, t_{n}\right) d x
$$

And the fluxes $F_{i-1 / 2}^{n}$ and $F_{i+1 / 2}^{n}$ are respectively calculated at the cells interfaces $x_{i-1 / 2}$ and $x_{i+1 / 2}$ (cf. Fig. 7). Integrating Eq. (1) over the $i$-th cell with length of $\Delta x_{i}$ yields:

$$
U_{i}^{n+1}=U_{i}^{n}-\frac{\Delta t}{\Delta x_{i}}\left[F_{i+1 / 2}^{n}-F_{i-1 / 2}^{n}\right]+\Delta t S_{i}
$$

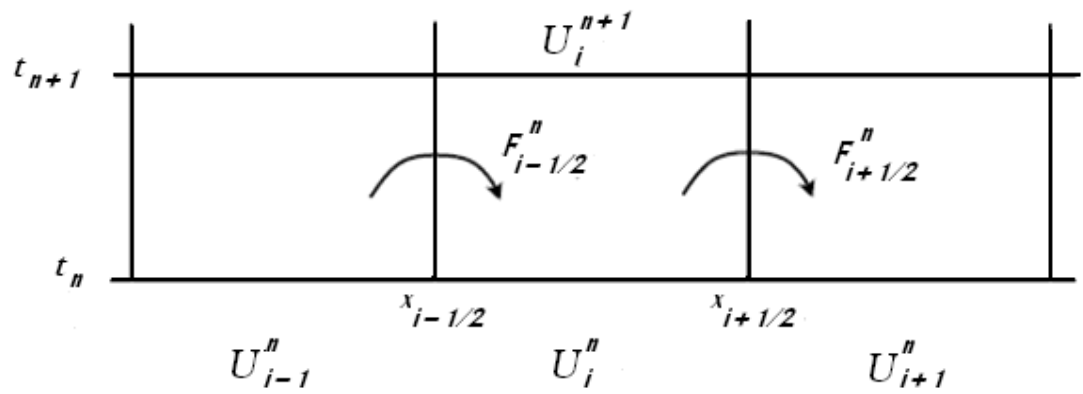

Fig. 7. Definition sketch of cell centered grid.

There are several approaches to evaluate the flux at the interfaces that construct various conservative numerical methods (Ying et al., 2003). We are interested in this work to shock capturing schemes based on solving Riemann problem.

The solution of the Riemann problem is the key ingredient of Godunov type scheme, the solution of the Riemann problem is computed by what is called a Riemann Solver, it is considered as a tool for the computation of the fluxes at the interfaces between the computational cells. Riemann problem represents (cf. Fig. 8) an initial value problem and defined as follows:

$$
U(x, 0)= \begin{cases}U_{l} & \text { if } x<0 \\ U_{r} & \text { if } x>0\end{cases}
$$

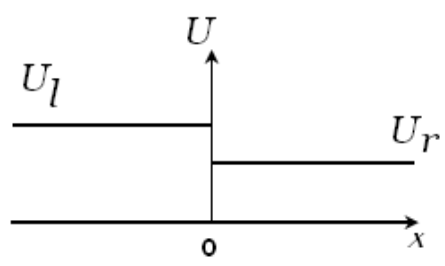

Fig. 8. Definition sketch of Riemann problem. 
In the literature, there are several types of Riemann solver; one can cite exact Riemann solver, but also approximate Riemann solvers that are easy to implement such as HHL solver (Harten et al., 1983) and Roe Riemann solver (Roe, 1981). Roe's solver, used in this study, is probably the most widely used Riemann solver to date. The basic idea is to convert hyperbolic system of conservation law to an equivalent linear one that is easier to solve by replacing the exact Jacobian in each interval by a constant Jacobian as follows:

$$
\hat{A}_{i-1 / 2}=\left[\begin{array}{cc}
0 & 1 \\
-\hat{u}^{2}+g \bar{h} & 2 \hat{u}
\end{array}\right]
$$

where

$$
\bar{h}=\frac{1}{2}\left(h_{i-1}+h_{i}\right), \hat{u}=\frac{\sqrt{h_{i-1}} u_{i-1}+\sqrt{h_{i}} u_{i}}{\sqrt{h_{i-1}}+\sqrt{h_{i}}}
$$

Godunov's approach indicated by the Eq. (4) is the basis of choc capturing methods (Godunov, 1959) where the conserved variable is approximated by a piecewise constant function (cf. Fig. 9a). In Godunov's scheme, the left- and right-states of the Riemann problem are taken from the average values of the variable over the cell on the left- and right-hand side of the interface respectively.

Higher-order Godunov-type schemes use a reconstruction procedure to estimate the variations of the conserved variable in the calculation cells. The variable in a given cell is reconstructed using the average values in the neighboring cells. This allows the gradients to be located more accurately, thus leading to more accurate estimates of the fluxes.

Most second-order schemes use a linear reconstruction of the conserved variable (cf. Fig. 9b) as:

$\tilde{U}_{i}^{n}=U_{i}^{n}+\left(x-x_{i}\right) a_{i}^{n}$

The slope $a_{i}^{n}$ of the profile within cell $i$ is calculated as the average slope between cells $i-1$ and $i+1$.

By limiting the slope of the reconstructed profile, spurious oscillations are eliminated from the solution. In fact, the contributions of the gradient of the variable are limited using a so-called limiter, for which many formulations have been proposed in the literature.

In this study, we are interested in Monotonic Central (MC) scheme. This choice is justified by numerous previous numerical tests (Korichi, 2006). MC limiter function is given by (Guinot, 2010):

$\Phi(\theta)=\max (0, \min ((1+\theta) / 2,2,2 \theta))$,

where $\Phi$ is the limiting function and $\theta$ represent the monotony indicator given by:

$$
\theta_{i+1 / 2}^{n}=\left\{\begin{array}{l}
\frac{U_{i}^{n}-U_{i-1}^{n}}{U_{i+1}^{n}-U_{i}^{n}} \text { if } C F L \geq 0 \\
\frac{U_{i+2}^{n}-U_{i+1}^{n}}{U_{i+1}^{n}-U_{i}^{n}} \text { if } C F L \leq 0
\end{array}\right.
$$

(b)

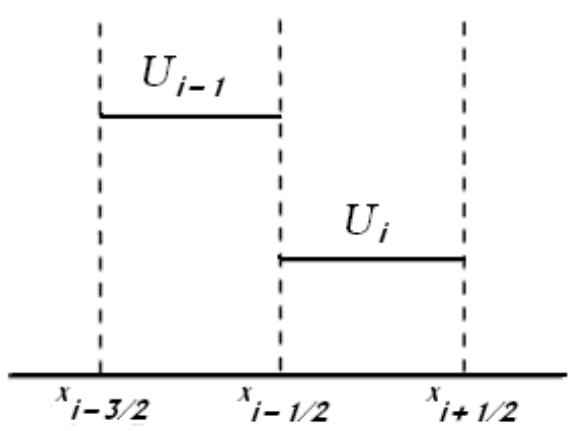

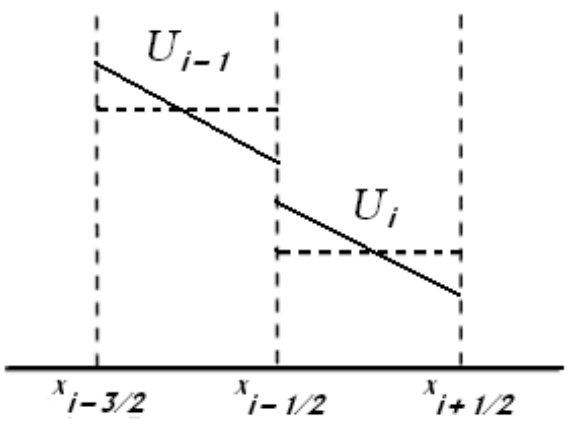

Fig. 9. Finite volume discretization (a) Piecewise constant (Godunov) (b) Piecewise linear (Monotonic Central). 
Fractional step method is used for the treatment of source term. The boundary conditions are treated by checking the flow regime. Which is verified by a simple calculation of the so-called Froude number $\mathrm{Fr}=\underline{u} /(\mathrm{g} h)^{1 / 2}$. It is defined as the ratio of flow velocity $u$ to celerity $\mathrm{c}$ of the waves in still water. When the flow is subcritical at a given boundary, only one condition is required. When the flow is supercritical entering the domain, two boundary conditions are needed. When the flow is supercritical leaving the domain, no boundary condition is required. Such approach is sufficient for finite volume method (Sanders, 2001).

\section{Numerical tests}

The primary objective of these tests is to verify the reliability of Godunov scheme and compare it with a MC scheme. The comparative study includes the examination of unsteady flow. It is a dam break test on a wet bottom in a smooth rectangular channel. These two schemes are checked using an analytical solution. The other application is a onedimensional flood wave simulation in Wadi Meker-

(a)

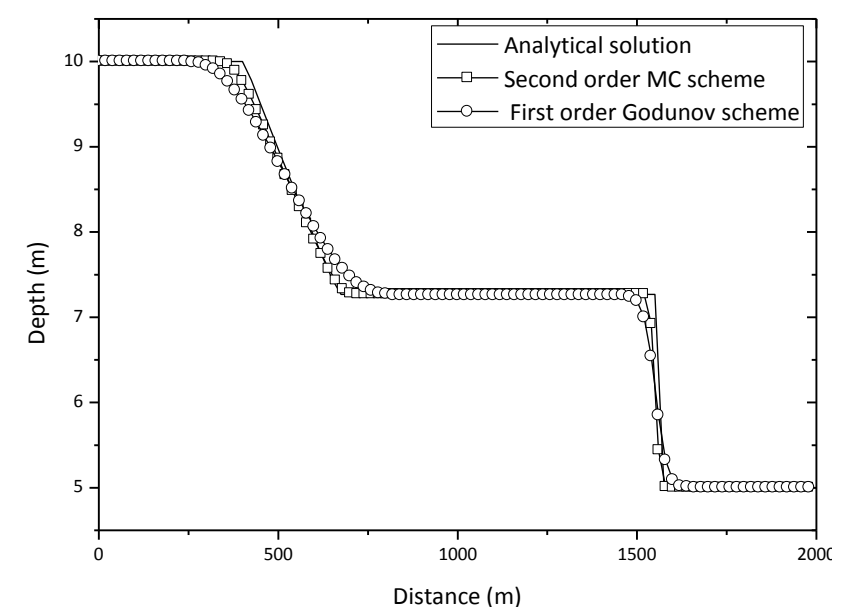

ra (October 1995) by applying the selected scheme. For calibration, we vary Manning coefficient to observe the influence of roughness on the numerical results. The flood hydrograph is used to validate the results.

\section{Dam failure test}

The first test is an examination of a dam break wave on wet bottom in a rectangular, smooth and horizontal channel. One admits an initial time step $\Delta t=0.1 \mathrm{~s}$ for a simulation period of $60 \mathrm{~s}$. The domain length is $2000 \mathrm{~m}$ divided into 2000 pieces. The rupture point is located at $x=1000 \mathrm{~m}$. The upstream water depth is initially $h_{l}=10 \mathrm{~m}$, while the initial water depth at downstream $h_{r}=5 \mathrm{~m}$. The initial discharge is null.

At the end of the simulation $(t=60 \mathrm{~s})$ we observe that the Godunov scheme diffuse near discontinuities, while the MC scheme has more stability and precision (cf. Fig. 10). (b)

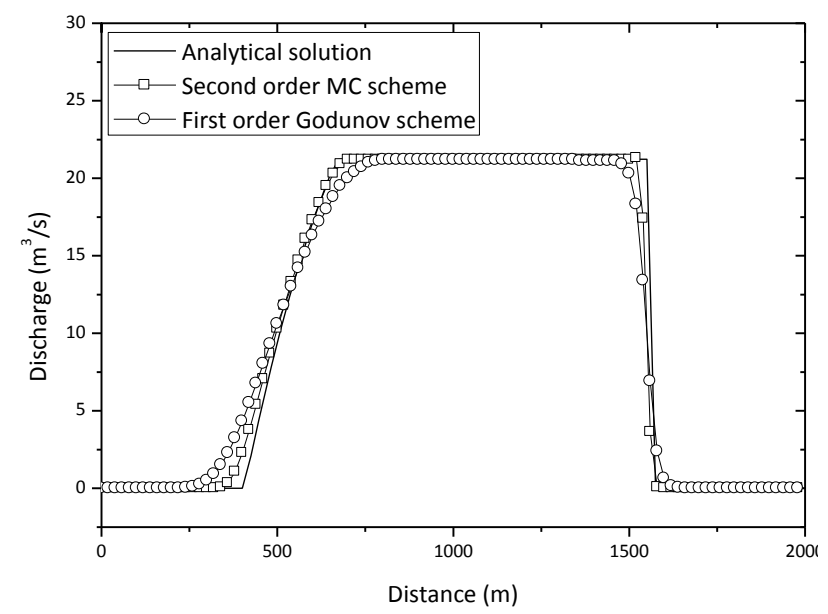

Fig. 10. Comparison of different schemes for dam break test (a) Depth, (b) Discharge.

\section{Simulation of flood wave at Wadi Mekerra in October 1995}

\section{Used data}

Based on the results of the first test, the selected scheme (Monotonic Central) is applied to simulate the flood wave dated on 11-12 October 1995. The channel length is about $44 \mathrm{~km}$ from Sidi Ali Benyoub station to Sidi Bel Abbes station. Fig. (11) shows a simplified longitudinal profile of Wadi Mekerra between these two stations where the stream is treated as a prismatic rectangular channel of width $b=18.6 \mathrm{~m}$. The boundary conditions are 
represented by a flood hydrograph observed at Sidi Ali Benyoub station while fixing the water depth in downstream at $0.6 \mathrm{~m}$.

To understand the influence of frictional forces on the flood wave shape, three Manning coefficients considered in this study are $(n=0.02,0.03$ and $0.04 \mathrm{~s} \mathrm{~m}^{-1 / 3}$ ); this choice is justified by the variability in the Wadi bed and the basin Landcover. Complete lists of the Manning coefficient, $n$ were established by Crausse (Crausse, 1951), Chow (Chow, 1959) and Graf (Graf, 1984) which ranges in general from 0.012 and 0.15 . For earthen and natural channels the Manning coefficient is between $0.02<n<0.05$. The simulated results are compared with recorded measurements at the downstream station.

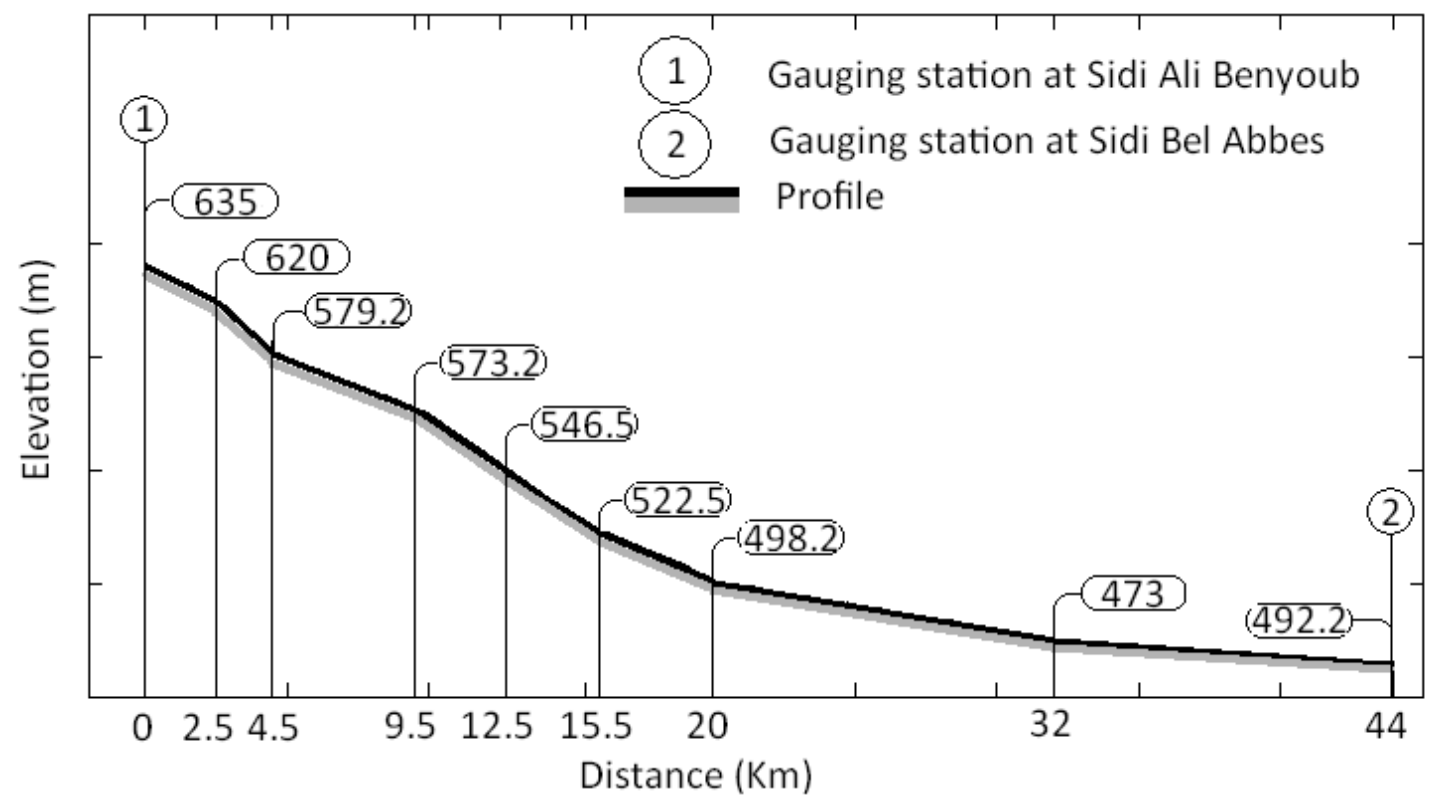

Fig. 11. Simulated longitudinal profile of Wadi Mekerra between Sidi Ali Benyoub and Sidi Bel Abbes stations.

The flow is initially uniform with a discharge $Q_{0}$ $=1.02 \mathrm{~m}^{3} \mathrm{~s}^{-1}$; while the maximum discharge recorded during this flood is $155 \mathrm{~m}^{3} \mathrm{~s}^{-1}$ through total time $t=48$ hours. The studied domain is divided into 100 cells. To keep the Courant number close to one, the time step is adapted as:

$\Delta t=\frac{C F L}{\Delta x}(|u|+\sqrt{\mathrm{g} h})$

Analysis and comments
Observations extracted from the results (cf. Fig. 13) show that the flood strength decreases according the increase in the Manning coefficients. It is direct consequence of the frictional forces that damp the impact of a high velocity gradient. Tab. 8 summarizes the main results. One notes that for Manning coefficient $n=0.02$, the maximum discharge is largely overestimated with an error of $0.07 \%$ and an advancement of 15 minutes. For Manning coefficient $n=0.03$ and 0.04 , the maximum flow rates are respectively 121.3 and 116.28 $\mathrm{m}^{3} \mathrm{~s}^{-1}$ but the rise time of flood wave is retarded. It reached 2.64 hours for the second case.

$\mathrm{T}$ a b 1 e 8. Comparison between the simulated and recorded results for different coefficient of Manning.

\begin{tabular}{lllll} 
& \multicolumn{2}{c}{ Simulated } & & Recorded at \\
\cline { 2 - 4 } & $n=0.02$ & $n=0.03$ & $n=0.04$ & Sidi Bel Abbes station \\
\hline Flood rising time $[\mathrm{h}]$ & 5.76 & 7.68 & 8.64 & 6 \\
Difference in flood rising time $[\mathrm{h}]$ & -0.24 & +1.68 & +2.64 & - \\
$Q_{\max }\left[\mathrm{m}^{3} \mathrm{~s}^{-1}\right]$ & 124.4 & 121.3 & 116.28 & 116 \\
Error $(Q)[\%]$ & 7 & 4 & 3 & - \\
\hline
\end{tabular}


The roughness influence is clearly established. However, the spatial distribution of roughness in the study area represents a major handicap for the numerical simulation of floods. The channel flow resistance is largely determined by the presence of dunes that usually develop in the beds. This resistance varies depending on the nature and topography of the Wadi, if it is minor bed (main channel) or major bed (floodplain). Udo et al., (2007) shows the relationship between roughness, expressed by the Chézy coefficient and discharge (cf. Fig. 12). They thus prove that the resistance in the main channel is much greater than that in the floodplain. Relationship (roughness, flow) is more linear in floodplains (Perumal et al., 2004).

In transient flows cases, flood modelling seems being complicated. In some hydraulic models, the roughness coefficient is directly related to the dunes sizes that are dimensioned by empirical relation- ships (Warmink et al., 2007). Other models consider the temporal evolution of these dunes (Paarlberg et al., 2006). Einstein and Barbarossa (1952), consider that the total roughness height of the main channel $\left(k_{\text {total }}\right)$ can be divided into a contribution of grains $\left(k_{\text {grain }}\right)$ and dunes $\left(k_{\text {dunes }}\right)$.

According to our results, the time required for the wave to reach Sidi Bel Abbes station is estimated at $t=6$ hours. We can divide the recession phase in two stages, the first covers 12 hours (6h to $18 \mathrm{~h}$ ) in which the simulated discharge are larger than recorded discharge. This is due in part to the water lamination by the spreading field formation (swamps), on the other hand, exclusion of affluents influence to the main thalweg. The second phase lasts from $t=18$ hours until the end of the simulation. It is thus observed that the simulation results and recorded hydrograph are clearly coincided.

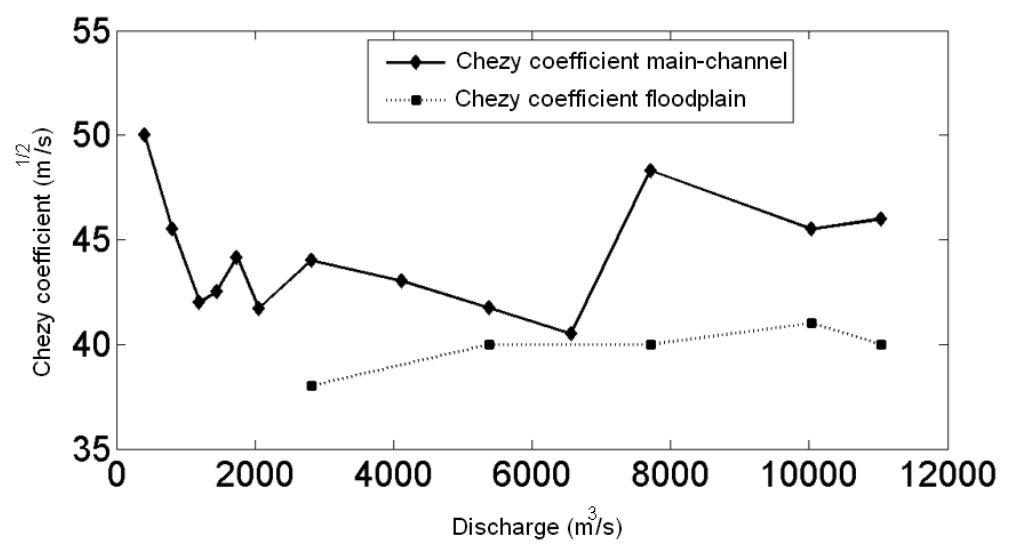

Fig. 12. Calibraion Chezy coefficient of main channel land the floodplain as a function of discharge (Udo et al., 2007).

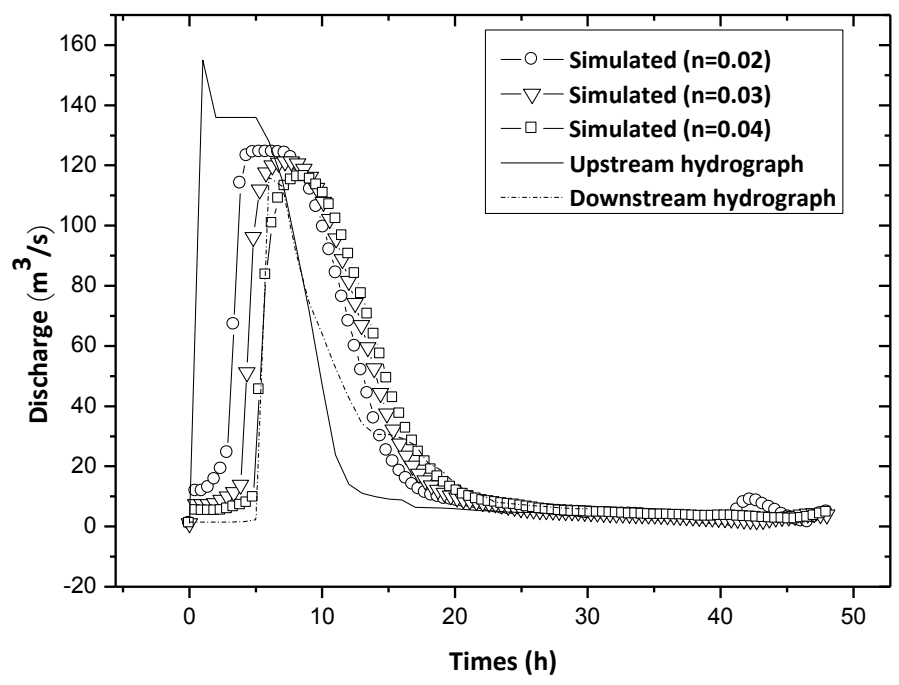

Fig. 13. Comparison between measured and simulated hydrographs for different Manning coefficients. 


\section{Summary and conclusion}

Wadi Mekerra, located in a semi-arid zone, is part of the ephemeral Wadis with temporal flow. In early autumn, it generates devastating floods that cause human and material damage. This is due to hydrological, geomorphological and human factors too. These floods threaten twenty five agglomerations. Since the 2006 disaster to date more than 120 billion dinars ( $\$ 14$ million) have been mobilized to cope with inundations. A substantial budget has been devoted to the concreting works on Wadi Mekerra channel. It is about 13 kilometers connecting Sidi Lahcen city to the north of the Sidi Bel Abbes city adding Wadi banks development. Other efficient techniques; the hillside dams of various sizes have been built to store water, contributing to cope with the high variability and reduce flood risk.

Methodologically, the flood forecasting and monitoring of changes in the flow magnitude are realized by numerical simulation of the flood wave. This simulation is performed using the simplified one-dimensional Saint-Venant model. Finite volume shock capturing schemes (Godunov and Monotonic Central) are applied. Source term is treated by using fractional step method. Numerical results analysis for the dam break test confirms that slope limiter Monotonic Central scheme is more advantageous for the accuracy and stability. However, the first order Godunov scheme present more diffusion at discontinuities. The MC scheme is thus applied to simulate the flood wave caused by Wadi Mekerra dated on October 11th, 1995. The variation of Manning coefficient ( $n=0.02,0.03$ and 0.04 ) confirms that maintenance activities in the bed can amortize the impact of the flood wave.

This promising work could be extended to the application of a two-dimensional model that takes into account both the storage coefficient influence (inflow-outflow) and also the spatial distribution of Manning coefficient. For more accuracy, application of well-balanced schemes rather than fractional step method is envisaged. Wetting and drying treatment is recommended too. An adaptive refined mesh applied to a proper digital elevation model would be a certain advantage (Begnudelli et al., 2008 ; Liang and Borthwick, 2008; Berger et al., 2010). New procedures in processing satellite images allow the calibration of the roughness module in the study area Schumann et al., (2007).

Other critical parameter has an interest in development of an appropriate model. It is about of the sediment transport generated in flood period. The silty-clay fraction increases with the width of Wadis and influences the service life of hillside dams located in the upstream (Albergel et al., 2004; De Araujo et al., 2006; Remini and Wassila, 2006; Ben Mammou and Louati, 2007).

Acknowledgements. The authors warmly thank anonymous reviewers that their comments and suggestions were highly appreciated.

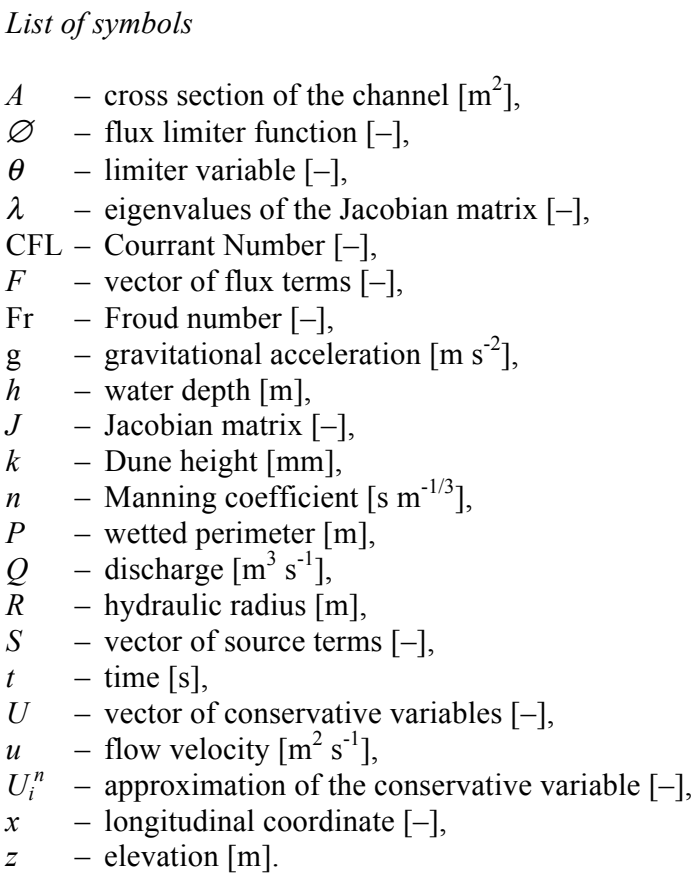

\section{REFERENCES}

ACHITE M. and MEDDI M., 2005: Variabilité spatiotemporelle des apports liquide et solide en zone semi-aride. Cas du bassin versant de l'Oued Mina (nord-ouest algérien). Rev. Sci. Eau, 18, 37-56.

ACHITE M. and OUILLON S., 2007: Suspended sediment transport in a semiarid water-shed, Wadi Abd, Algeria (1973-1995). J. Hydrol, 343, 187-202.

ALBERGEL J., NASRI S., LAMACHËRE J. M., 2004: HYDROMED - Programme de recherche sur les lacs collinaires dans les zones semi-arides du pourtour méditerranéen. Rev. Sci. Eau, 17, 133-151.

ALEXANDROV Y., LARONNE B., REID I., 2006: Intraevent and inter-seasonal behaviour of suspended sediment in flash floods of the semi-arid northern Negev, Israel. Geomorphology, 85, 85-97.

ANAT, Agence Nationale pour la Conservation de la Nature, 2000: Programme national sur la conservation de la nature, $40 \mathrm{p}$.

ANTEVS, ERNST, 1952:"Arroyo-Cutting and Filling." J. Geol., Vol. 60, No. 4, pp. 375-385.

ARAB A., LEK S., LOUNACI A. and PARK Y. S., 2004: Spatial and temporal patterns of benthic invertebrate communities in an intermittent river (North Africa). Ann Limnol. - Int. J. Lim, 40, 317-327. 
ARGYROUDI A., CHATZINIKOLAOU Y., POIRAZIDIS K. and LAZARIDOU M., 2009: Do intermittent and ephemeral mediterranean rivers belong to the same river type? Aquat Eco., 43, 465-476.

ASKRI H., BELMECHERI A., BENRABAH B., BOUDJEMA A., BOUMENDJEL K., DAOUDI M., DRID M., GHALEM T., DOCCA A. M., GHANDRICHE H., GHOMARI A., GUELLATI N., KHENNOUS M., LOUNICI R., NAILI H., TAKHERIST D., TERKMANI M., 1993: Geology of Algeria. Contribution from SONATRACH Exploration Division, Research and Development Centre and Petroleum Engineering and Development Division (SCHLUMBERGER WEC SONATRACH)

AUDUSSE, E., BOUCHUT, F., BRISTEAU, M.O., KLEIN, R. and PERTHAME, B., 2004: A fast and stable wellbalanced scheme with hydrostatic reconstruction for shallow water flows. SIAM. J. Scientific Computing, 25, 6, pp. 2050-2065.

BARRE DE SAINT VENANT, 1871: Théorie du mouvement non permanent des eaux. C.R.A.S., Paris, $V$, 73, 147.

BARRIENDOS M. and RODRIGO F. S., 2006: Study of historical flood events on Spanish rivers using documentary data. Hydrol. Sci. J., 51, 5, 765-783.

BEGNUDELLI L., SANDERS B. F. and BRADFORD S. F., 2008: Adaptive Godunov-Based Model for Flood Simulation. J. Hydraul. Engng., ASCE, Vol. 134, No. 6, 714-725.

BEGNUDELLI L. and SANDERS B. F., 2007: Simulation of the St. Francis Dam-Break Flood. J. Engng Mech., Vol. 133, No. 11, 1200-1212.

BEN MAMMOU A. and LOUATI M. H., 2007: Evolution temporelle de l'envasement des retenues de barrages de Tunisie. Rev. Sci. Eau 20.

BENKACI A. T., and DECHEMI N., 2004: Modélisation pluie-débit journalière par des modèles conceptuels et 'boîte noire'; test d'un modèle neuroflou. Hydrol. Sci. J. 49, 5, 919-930.

BENKHALDOUN F., EL MAHI I. and SEAID M., 2007: Well-balanced finite volume schemes for pollutant transport by shallow water equations on unstructured meshes. J. Computat. Physics, vol. 226, $\mathrm{n}^{\circ} 1$, pp. 180-203.

BERGER M. J., GEORGE D. L., LEVEQUE R. J., and MANDLI K., 2010: The GeoClaw software for depthaveraged flows with adaptive refinement, Preprint submitted to Elsevier.

BORSALI A. H., BEKKI A., HASNAOUI O., 2005: Aspect hydrologique des catastrophes naturelles: "Inondation, glissement de terrains » Etude d'un cas: Oued Mékerra (Sidi bel abbés); XXIII ${ }^{\text {iemes }}$ Rencontres Universitaires de Génie Civil (Risque et Environnement).

BOUASRIA S., KHALLADI. M., KHALDI. A., 2010: Ralentissement Dynamique des Inondations au niveau d'un bassin Versant de 1' Ouest Algérien: cas de l'Oued Mekerra (Sidi Bel Abbes), European J. Scientif. Res., Vol. 43, No. 2, pp. 172-182.

BOURI, S., GASMI, M., JAOUADI, M., SOUISSI, I., LAHLOU MIMI, A. and BEN DHIA H., 2007: Etude intégrée des données de surface et de subsurface pour la prospection des bassins hydrogéothermiques: cas du bassin de Maknassy (Tunisie centrale). Hydrol. Sci. J., 52, 6, 1298 -1315 .

BOYLE S. J., TSANIS I. K., KANAROGLOU P. S., 1998. Developing géographie information Systems for land use impact assessment in flooding conditions. J. Water Resour Ping, and Mgmt, ASCE, 124, 2, 89-98.
BRACKEN L. J. (nee BULL), COX N. J. and SHANNON J., 2008: The relationship between rainfall inputs and flood generation in south-east Spain. Hydrological Processes, 22, 5, 683-696.

BRÁZDIL R. and KUNDZEWICZ Z. W., 2006: Historical hydrology-Editorial. Hydrol. Sci. J., 51, 5, 733-738.

BRETON C. and MARCHE C., 2000: Une aide à la décision pour le choix des interventions en zone inondable, Rev. Sci. Eau 14/3, 363-379.

CAMARASA A. M. and TILFORD K. A., 2002: Rainfallrunoff modelling of ephemeral streams in the Valencia region (eastern Spain). Hydrol. Processes, 16, 3329-3344.

CHAPONNIÈRE A., BOULET G., CHEHBOUNI A. and ARESMOUK M., 2007: Understanding hydrological processes with scarce data in a mountain environment. Hydrol. Processes.

CHERIF El., ERRIH M. and MADANI H., 2009: Modélisation statistique du transport solide du bassin versant de l'Oued Mekerra (Algérie) en zone semi-aride méditerranéenne, Hydrological Sciences J., Vol. 54, Issue 2.

CHOW V. T., 1959: Open-channel hydraulics. McGraw-Hill.

COLOMBANI, J., OLIVRY, J., C., and KALLEL, R., 1984: Phénomènes exceptionnels d'érosion et de transport solide en Afrique aride et semi-aride. Challenges in African Hydrology and Water Resources (Proceedings of the Harare Symposium). IAHS Publ. n. 144.

COSTELLOE J. F., GRAYSON R. B., MCMAHON T. A., 2005: Modelling streamflow in a large anastomosing river of the arid zone, Diamantina River, Australia Original Research Article. J. Hydrol., Vol. 323, Issues 1-4, 30 May, pp. 138-153.

CRAUSSE E., 1951: Hydraulique des canaux découverts, Eyrolles.

CUDENNEC C., SLIMANI M. and LE GOULVEN P., 2005: Accounting for sparsely observed rainfall space-time variability in a rainfall-runoff model of a semiarid Tunisian basin. Hydrol. Sci. J., 50, 4, 617-630.

CUNGE J., HOLLY F. and VERWEY A., 1980: Practical aspects of computational river hydraulics. Pitman Publishing Ltd, 420 pages.

DE ARAUJO J. C., GÜNTNER A. and BRONSTERT A.: 2006: Loss of reservoir volume by sediment deposition and its impact on water availability in semiarid Brazil. Hydrol. Sci. J., 51, 1, 157-170.

DECHEMI N., BERMAD A., HAMRICHE A., 1994: Simulation des débits moyens mensuels en zone semi-aride par l'analyse en composantes principales (ACP), Hyrol. Continent., vol. 9, no 1. 17-24.

DGPC. Direction Générale de la Protection Civil, 2000: Problématique de l'inondation à Sidi Bel Abbes. Rapport.

DGPC. Direction Générale de la Protection Civil, 2008: Les inondation en Algérie. Rapport.

EINSTEIN, H. A. and BARBAROSSA, N. L., 1952: River channel roughness. Transaction ASCE, 117, 1121-1146.

FILLIOL J., 1954: Influence des crues et de la végétation sur la mobilité du lit mineur de quelques rivières françaises. Revue de géographie alpine. Tome 42, $\mathrm{N}^{\circ} 1$. pp. 163-169.

GARCIA-NAVARRO P., and VAZQUEZ-CENDON M. E., 2000: On the numerical treatment of the source terms in the shallow water equations.Comput. Fluids, 29, 951-979.

GEORGE D. L. and LEVEQUE R. J., 2006: Finite volume methods and adaptive refinement for global tsunami propagation and local inundation. Sci. of Tsunami Hazards, 24, 5, 319-328. 
GODUNOV S. K., 1959: A difference method for numerical calculation of discontinuous solutions of the equations of hydrodynamics. Mat. Sb., 47, pp. 271-306.

GRAF W. H., 1984: Hydraulics of Sediment Transport, McGraw-Hill, New York.

GREGORY R., LICHTENSTEIN S., SLOVIC P., 1993: Valuing environmental resources: a constructive approach, In: J. Risk and Uncertainty, 7, 177-197.

GUINOT V., 2010: Wave Propagation in Fluids: Models and Numerical Techniques. 560 pages, WILEY-ISTE.

HAASE D., WEICHEL T., VOLK M., 2003: Approaches towards the analysis and assessment of the disastrous floods in Germany in August 2002 and consequences for land use and retention areas. In: Vaishar A., Zapletalova J., Munzar J. (eds.), Regional Geography and its Applications. Proceedings of the 5th Moravian Geographical Conference CONGEO '03, 51-59

HANSSON K., DANIELSON M., EKENBERG L., 2008: A framework for evaluation of flood management strategies. J. Environment. Managem., 86, 465-480.

HARTEN A., LAX P. D., VAN LEER B., 1983: On upstream differencing and Godunov-type schemes for hyperbolic conservation laws. J. Calculation Physics, 50, 235-269.

HORRITT M. S. and BATES P. D., 2002: Evaluation of 1D and 2D numerical models for predicting river flood inundation. J. Hydrol., 268, Issues 1-4, 87-99.

HREICHE A., NAJEM W. and BOCQUILLON C., 2007: Hydrological impact simulations of climate change on Lebanese coastal rivers. Hydrol. Sci. J., 52, 6, 1119-1133.

HUANG Z., ZHOU J., SONG L., LU Y., ZHANG Y., 2010: Flood disaster loss comprehensive evaluation model based on optimization support vector machine. Expert Systems with Applications, 37, Issue 5, 3810-3814.

HUGHES, D. A., 1995: Monthly rainfall-runoff models applied to arid and semiarid catchments for water resource estimation purposes. Hydrol. Sci. J., 40, 6, 751-769.

ISH-SHALOM-GORDON N. and GUTTERMAN Y., 1991: Soil disturbance by a violent flood in Wadi Zin in the Negev Desert Highlands of Israel. Arid Soil Research and Rehabilitation, 5, 251-260.

JONKMAN S. N., BOČKARJOVA M., KOK M., BERNARDINI P., 2008: Integrated hydrodynamic and economic modelling of flood damage in the Netherlands. Ecological Economics, 66, 77-90.

KESSERWANI G., LIANG Q., 2010: Well-balanced RKDG2 solutions to the shallow water equations over irregular domains with wetting and drying. Computers \& Fluids, 39, 2040-2050.

KINGUMBI A., BARGAOUI Z., LEDOUX E., BESBES M. and HUBERT P., 2007: Modélisation hydrologique stochastique d'un bassin affecté par des changements d'occupation: cas du Merguellil en Tunisie centrale. Hydrol. Sci. J., 52, 6, 12132-1252.

KORICHI Kh., 2006: Application de la méthode des volumes finis pour la simulation numérique des écoulements à surface libre, Master theisis, Mascara University. Algeria.

LAJILI-GHEZAL L., 2007: Elaboration d'un modèle d'érosion hydrique à la parcelle (PLAG) et son application pour l'estimation des apports en sédiments en zone semi-aride tunisienne. Hydrol. Sci. J., 52, 6, 1285-1297.

LAX P. D. and WENDROFF B., 1960: Systems of conservation laws. Comm. Pure Appl. Math., 13, pp. 217-237.

LEBDI F., FDHILA M. K. and HZAMI A., 2006: Modélisation de la dynamique fluviale de la Medjerda: impact de l'évolution morphologique du lit sur l'écoulement. In: The Future of Drylands, Side event Hydrological changes in arid and semiarid areas under climatic and human influences: focus on the Mediterranean region (Int. Conf., Tunis, Tunisia, 21 June 2006).

LEE S. H. and WRIGHT N. G., 2010: Simple and efficient solution of the shallow water equations with source terms. Int. J. Num. Methods in Fluids, 63, 3, pp. 313-340.

LEVEQUE R. J., 1998: Balancing source terms and flux gradients in high resolution Godunov methods the quasisteady wave propagation algorithm. AMS

LEVEQUE R. J., 2004: Finite volume method for hyperbolic problems. Cambridge university press, 580 pages.

LIANG Q. and BORTHWICK A. G. L., 2008: Adaptive quadtree simulation of shallow flows with wet-dry fronts over complex topography. Computers \& Fluids, 38, 221-234.

LIANG Q. and WANG Y., 2010: A Well-balanced Shallow Flow Solver for Coastal Simulations. Int. J. Offshore and Polar Engng., Vol. 20, No. 1, pp. 41-47.

LIGGETT J. A. and CUNGE J., 1975: Numerical methods of solution of the unsteady flow equations in open channels. Unsteady Flow in Open Channels, K. Mahmood and V. Yevjevich, Eds.,Water Resources Publications, Fort Collins, Colorado.

LÓPEZ-MORENO J. I., BEGUERIA S., VICENTESERRANO S. M. and GARCÍA-RUIZ J. M., 2007: Influence of the North Atlantic Oscillation on water resources in central Iberia: precipitation, streamflow anomalies, and reservoir management strategies. Wat. Resour. Res., 43, W09411.

MARTINEZ-MENA M., ALVAREZ ROGEL J., ALBALADEJO J., CASTILLO V. M., 1999: Influence of vegetal cover on sediment particle size distribution in natural rainfall conditions in a semiarid environment. Catena, vol. 38, pp. $175-190$.

MCINTYRE N., AL-QURASHI A. and WHEATER H., 2007: Regression analysis of rainfall-runoff data from an arid catchment in Oman. Hydrol. Sci. J., 52, 6, 1103-1118.

MEDDI M., KHALDI A., and LEDDI H., 1998: Etude du transport solide dans le nord de l'Algerie. IAHS Publication, 393-397.

MEYER D. F., 1992: Significance of sediment transport in arroyo development. In: U.S. Geological Survey, Books and Open-File Reports Section; Box 25425, Federal Center, Denver, CO 80225-0425. Water-Supply Paper 2349.

MOLIĖRE D. R., LOWRY J. B. C. and HUMPHREY C. L., 2009: Classifying the flow regime of data-limited streams in the wet-dry tropical region of Australia. J. Hydrol., 367, $1-13$.

MORAIS M., PINTO P., GUILHERME P., ROSADO J. and ANTUNES I., 2004: Assessment of temporary streams: the robustness of metric and multimetric indices under different hydrological conditions. Hydrobiologia, 516, 229-249.

MOUSSA R., CHAHINIAN N. and BOCQUILLON C., 2007: Distributed hydrological modelling of a Mediterranean mountainous catchment - Model construction and multi-site validation. J. Hydrol. 337, 35-51.

MUDD S. M., 2006: Investigation of the hydrodynamics of flash floods in ephemeral channels: Scaling analysis and simulation using a shock-capturing flow model incorporating the effects of transmission losses. J. Hydrol., 324, $65-79$. 
NASRI S., 2007: Caractéristiques et impacts hydrologiques de banquettes en cascade sur un versant semi-aride en Tunisie centrale. Hydrol. Sci. J. 52, 6, 1134-1145.

NASRI S., CUDENNEC C., ALBERGEL J. and BERNDTSSON R., 2004: Use of a geomorphological transfer function to model design floods in small hillside catchments in semiarid Tunisia. J. Hydrol. 287, 197-213.

NOUH M., 2006: Wadi flow in the Arabian Gulf states. Hydrol. Processes, 20, 2393-2413.

OLFERT A. SCHANZE J., 2008: New approaches to ex-post evaluation of risk reduction measures. Flood Risk Management: Research and Practice, 203.

OUACHANI R., BARGAOUI Z. and OUARDA T., 2007: Intégration d'un filtre de Kalman dans le modèle hydrologique HBV pour la prévision des débits. Hydrol. Sci. J. $52,2,318-337$.

OUESLATI O., DE GIROLAMO A., ABOUABDILLAH A. and LO PORTO A., 2010: Attempts to flow regime classification and characterisation in mediterranean streams using multivariate analysis. International Workshop. Advances in statistical hydrology, Taormina, Italy.

PAARLBERG A. J., DOHMEN-JANSSEN C. M., HULSCHER S. J. M. H. VAN DEN BERG J. and TERMES A. P. P., 2006: Modelling morphodynamic evolution of river dunes. In: Ferreira, Alves, Leal, and Corsado (Eds.), Proc. of Riverflow 2006, 969-978. Taylor and Francis Group, London.

PEDRO F., MALTCHIK L., BIANCHINI J. I., 2006: Hydrologic cycle and dynamics of aquatic macrophytes in two intermittent rivers of the semi-arid region of Brazil. Braz. J. Biol., 66 (2B), 575-585.

PERUMAL M., SHRESTHA K. B. and CHAUBE U. C., 2004: Reproduction of hysteresis in rating curves. J. Hydraul Engng., 130, 9, 870-878.

PILGRIM D. H., CHAPMAN T. G. and DORAN D. G., 1988: Problems of rainfall-runoff modelling in arid and semiarid regions. Hydrol. Sci. J., 33, 4, 379-400.

POFF N. L. and WARD J. V., 1989: Implications of streamflow variability and predictability for lotic community structure: a regional analysis of streamflow patterns. Can. J. Fisheries and Aquatic Sciences, 46, 1805-1818.

PORATH D. and ADAR E., 1992: The role of light and water in the establishment of two Mullein species (Verbascum Sinaiticum Benth. and Fruticulosum Post) on an erratically flooded gravelbed. J. Arid Environments, Vol. 22, pp. 231-244 .

PUIGDEFABREGAS J. and MENDIZABAL T., 1998: Perspectives on desertification: western Mediterranean. J. Arid Environ., 39, 209-224.

RAAIJMAKERS R., KRYWKOW J. and VEEN VAN DER A., 2008: Flood risk perceptions and spatial multi-criteria analysis: an exploratory research for hazard mitigation. Natural Hazards, 46, 3, 307-322.

RACHMAN A, ANDERSON S. H., GANTZER, C. J., THOMPSON A. L., 2003: Influence of long-term cropping system on soil physical properties related to soil erodibility. Soil Sci. Soc. Am. J., 67, 637-644.

REMINI B. and WASSILA H., 2006: L'envasement des barrages des régions semi-arides et arides: quelques exemples algériens. In: The Future of Drylands, Side event Hydrological changes in arid and semiarid areas under climaticand human influences: focus on the Mediterranean region (Int. Conf., Tunis, Tunisia, 21 June 2006).
ROE P. L., 1981: Approximate Riemann solvers, parameter vectors and difference schemes. J. Calcul. Phys., 43, 357 -372 .

ROGERS B. D., BORTHWICK A. G. L. and TAYLOR P. H., 2003: Mathematical balancing of flux gradient and source terms prior to using Roe's approximate Riemann solver. J. Computat. Physics, 192, 2, pp. 422-451.

ROZOS, E., EFSTRATIADIS, A., NALBANTIS, I. and KOUTSOYIANNIS D., 2004: Calibration of a semidistributed model for conjunctive simulation of surface and groundwater flows. Hydrol. Sci. J., 49, 5, 819-842.

SADEG M., 2003: Contribution a l'étude des hydrogrammes de crue en zone semi aride application au modèle de l'hydrogramme unitaire. Mémoire de Magister. Algerie: Univ. Mascara.

SANDERS B. F., 2007: Evaluation of on-line DEMs for flood inundation modeling, Advances in Wat. Resour., 30, 1831-1843 .

SANDERS B. F., 2001: High-Resolution and Non-Oscillatory Solution of the St. Venant Equations in Non-Rectangular and Non-prismatic Channels. J. Hydraul. Res., 39, 3, 321-330 .

SCHUMANN G., MATGEN P., HOFFMANN L., HOSTACHE R., PAPPENBERGER F., PFISTER L., 2007: Deriving distributed roughness values from satellite radar data for flood inundation modelling. J. Hydrol., 344, 96-111.

SHARMA K. D. and MURTHY J. S. R., 1998: A practical approach to rainfall-runoff modelling in arid zone drainage basins. Hydrol. Sci. J., 43, 3, 331-348.

SIVAPALAN M., TAKEUCHI K., FRANKS S. W., GUPTA V. K., KARAMBIRI H., LAKSHMI V., LIANG X., MCDONNELL J. J., MENDIODO E. M., O'CONNELL P. E., OKI T., POMEROY J. W., SCHERTZER D., UHLENBROOK S. and ZEHE E., 2003: IAHS Decade on Prediction in Ungauged Basins (PUB), 2003-2012: Shaping an exciting future for the hydrological sciences. Hydrol. Sci. J., $48,6,857-880$.

SMAKHTIN V.U., 2001: Low flow hydrology: a review. J. Hydrol., 240, 147-186.

STUCKY, 2005: Cartographie des zones inondable dans le bassin de l'Oued Mekerra. Groupement d' etudes STUCKY - ENHYD, STUCKY SA, Alger.

TARDY Y., and PROBST J. L., 1992: Sécheresses, crises climatiques et oscillations tele-connectees du climat depuis cent ans. Sécheresse, 3, 25-36.

TERFOUS A., MEGNOUNIF A., BOUANANI A., 2001: Etude du transport solide en suspension dans l'Oued Mouilah (Nord Ouest Alge'rien). Rev. Sci. de 1'Eau, 14, 2, 173-185 .

TORO, ELEUTERIO F., 2006: Riemann Solvers and Numerical Methods for Fluid Dynamics - A Practical Introduction (2nd Edition), Springer, New York.

TOUAÏBIA B., GOMER D., AÏDAOUI A. and ACHITE M., 2001: Quantification et variabilité temporelles de l'écoulement solide en zone semi-aride, de l'Algérie du Nord. Hydrol. Sci. J., 46, 1, 41-53.

UDO J., BAKKER M. and TERMES P., 2007: SOBEK-model Rijn; hydraulische calibratie. Report PR1158. (In Dutch.) HKV Consultants, Lelystad, the Netherlands.

VAN LEER B., 1977: Towards the ultimate conservative difference scheme IV. A new approach to numerical convection. J. Comput. Phys, page pp. 276-299, 23. 
WANG J. S., NI H. G. and HE Y. S., 2000: Finite-difference TVD scheme for the computation of dam-break problems. ASCE J. Hydraul. Engng., ASCE, 126, 4, 253-262.

WARMINK, J. J., BOOIJ, M. J., VAN DER KLIS, H. and HULSCHER S. J. M. H., 2007: Uncertainty in water level predictions due to various calibrations. In: C. Pahl-Wostl (Ed.), Proc. of CAIWA 2007, Basel, Switserland, 1-18.

WHEATER H. S., SOROOSHIAN S. and SHARMA K. D., 2006: Hydrological Modelling for Arid and Semi-arid Areas. Cambridge University Press, Cambridge, UK.

XOPLAKI E., GONZALEZ-ROUCO J. F., LUTERBACHER J. and WANNER H., 2004: Wet season Mediterranean precipitation variability: influence of large-scale dynamics and trends. Clim. Dyn., 23, 63-78.

YING, X., KHAN, A. A., and WANG S. S. Y., 2003: An upwind conservative scheme for Saint-Venant equations (submitted to J. Hydraul. Engng., ASCE).
YING X., WANG S. S. Y. and KHAN A., 2004: Numerical simulation of flood inundation due to dam and levee breach. National Center for Computational Hydroscience and Engineering, The University of Mississippi.

ZAHAR Y. and ALBERGEL J., 2006: Le rétrécissement du lit de la basse vallée de la Medjerda suite à la construction du barrage Sidi Salem et ses conséquences durant les inondations 2003. In: The Future of Drylands, Side event Hydrological changes in arid and semiarid areas under climatic and human influences: focus on the Mediterranean region (Int. Conf., Tunis, Tunisia, 21 June 2006).

ZHOU J. G., CAUSON D. M., MINGHAM C. G., and INGRAM D. M., 2001: The Surface Gradient Method for the Treatment of Source Terms in the Shallow Water Equations. J. Comput. Phys. 168, 1-25.

Received 21 December 2011 Accepted 13 March 2012 